\title{
Expansion of Anopheles maculipennis s.s. (Diptera: Culicidae) to northeastern Europe and northwestern Asia: Causes and Consequences
}

Yuri M Novikov ${ }^{1 *}$ and Oleg V Vaulin ${ }^{2}$

\begin{abstract}
Background: The burden of malaria infection in the modern world remains significant. Specific changes in the relative proportions of malaria vector mosquitoes, Maculipennis Complex species, in the south of Western Siberia over the past 25 years of the $20^{\text {th }}$ century have attracted wide attention as an indicator of their dynamic geographical distribution. In Eurasia, studies of fluctuations in the borders of areas occupied by sibling species of this complex, as well as their relative proportions in the areas where they are sympatric are epidemiologically important.
\end{abstract}

Methods: Species identity and chromosomal polymorphisms within each population were defined by cytogenetic analysis of polytene chromosomes of third- and fourth-instar larvae and adult females of Anopheles mosquitoes collected over the period from 1973 to 2012. A total of 37 Anopheles samples (3,757 specimens) from the Ukraine, European Russia and the Urals were studied. To identify An. messeae s.l. cryptic species A and B, polymerase chain reaction and restriction fragment length polymorphisms of the second internal transcribed spacer rRNA genes sequences (ITS2 PCR-RFLP) were used.

Results: An. maculipennis s.s. is expanding to the northeast at a speed of approximately $30 \mathrm{~km}$ per year. In 2008 or 2009, this species appeared in the Southern Urals. The emergence of An. maculipennis in this region was accompanied by a decrease in the proportions of An. messeae A and An. beklemishevi and by an increase in the proportion of An. messeae B within An. messeae s.l. It is highly likely that the southwestern border of An. beklemishevi distribution area could shift in the same direction as expanding area of An. maculipennis.

Conclusions: The geographical distribution of the Palaearctic mosquito species of the Maculipennis Complex is undergoing a gradual shift. Changes detected in the species distribution can be considered as a component of the biocenotic process triggered by global warming. Both the warming itself and consequent expansion of An. maculipennis s.s. to the northeast, followed by changes in the species composition of Anopheles as well as their relative proportions and fluctuations in the species areas, exacerbate the epidemiology of malaria infection in Eurasia.

Keywords: Global warming, Changes in distribution areas, Cryptic species, Anopheles maculipennis, Anopheles messeae s.l, Anopheles beklemishevi, Cytogenetics, ITS2 PCR-RFLP, Ecological niche

\footnotetext{
* Correspondence: yu.m.novikov@gmail.com

'Department of Cytology and Genetics of Tomsk State University, Tomsk,

Russia

Full list of author information is available at the end of the article
} 


\section{Background}

Malaria remains a serious health issue in the contemporary world, being one of the major causes of death from infectious diseases worldwide. Global epidemiological situation in relation to malaria spread remains complicated $[1,2]$. The complexity and danger of the situation are aggravated by progressive global warming [3]. Manson [4] pointed out the direct role of temperature on the spread of malaria infection. Its indirect role is also significant, as temperature affects the duration of life cycle both of disease agents and vectors [5,6]. Despite being closely related, species of the Anopheles family differ in their physiology and ecology, including temperature sensitivity. Thus, changes in regional temperatures can influence the geographical distribution of Anopheles species as well as their interactions in the regions where the species are sympatric. Due to variable abilities of different species for transmission of malaria [7-9], global warming can result in profound changes in the risk of malaria infection in many regions of the world. Understandably, with a rise of annual average temperature the duration of warm time of the year will increase, making it possible for southern, i.e. most effective, Plasmodium transmitters [7] to invade the north of Eurasia. At the time when global warming had been admitted to be a serious issue, the borders of areas occupied by sibling species within Anopheles maculipennis Mg. taxon [7,8,10-12] were hardly defined [13-16]. In light of the above facts, refinement of these borders and analysis of their dynamics is becoming increasingly important. Climate projections can be used to predict dynamics of the borders $[17,18]$; in a number of studies both actual changes and likely future changes of the borders were reported [8,19-22]. Diverse responses to global warming are observed in different groups of species [23-25]. We believe that the present study, which was aimed to address the dynamics of the northeastern border of Anopheles maculipennis s.s. distribution area, will provide important insights into the role of global climate change in geographical distribution of the Palaearctic mosquito species of the Maculipennis Complex and its disease-relevant consequences.

Lack of consensus in views on the structure of $A n$. messeae taxon presents a major obstacle in understanding of speciation-related events within Palaearctic Maculipennis Complex. Based on non-random combinations of chromosome inversions in natural populations as well as assortative mating and different ecological features, as early as in 1984 it was suggested that $A n$. messeae includes two cryptic species. These were provisionally named $A n$. messeae A and An. messeae B [26]. The existence of these two species was confirmed by taxonoprint DNA analysis [27]. Some researchers [22,28] still regard An. messeae as a single polytypic, polymorphic species. Another research group isolated a new species, $A n$. daciae, from $A n$. messeae [29]. Based on the results of molecular-genetic research, $A n$. daciae appeared to be identical to $A n$. messeae A [30]. For this reason, in the present study the latter $A n$. messeae cryptic species will be referred to as $A n$. messeae A. An. messeae s.l. will therefore refer to both cryptic species $\mathrm{A}$ and $\mathrm{B}$.

\section{Methods}

Third and fourth instar Anopheles larvae and adult females were used. Locations, time of collection and relevant numerical data are given in Table 1. Larvae were obtained from still or partially flow-through fresh water reservoirs, as well as a brackish water lake (Muldakkul, located $15 \mathrm{~km}$ to the west of Magnitogorsk, Ozernoe, Republic Bashkortostan). Imagoes were collected in cattle barns. Larvae were fixed in Clark's solution (100\% ethanol and glacial acetic acid 3:1) or $96 \%$ ethanol. Squash preparations of salivary glands of larvae and Malpighian tubules of adult females were prepared as described elsewhere [31,32]. Species identification and analysis of chromosomal inversions in An. messeae karyotypes were performed using polytene chromosomes maps described in [14,33]. Determination of species composition in the populations was reported in part previously [34]. The inversion variants of polytene chromosomes were traditionally marked by indicating the polymorphic chromosome element of the polytene complex $(1 \mathrm{~L}, 2 \mathrm{R})$ and its variants [33]. Variants $1 \mathrm{~L} / 1 \mathrm{~L}$, $1 \mathrm{~L} / 1 \mathrm{~L} 1,1 \mathrm{~L} 1 / 1 \mathrm{~L} 1$ of the left arm of chromosome 1 (sex, or X-chromosome) in females are homozygous standard, heterozygous and homozygous inverted sequences, respectively. Variants $1 \mathrm{~L} / \neg$ and $1 \mathrm{~L} 1 / \neg$ in males are hemizygous standard and inverted sequences, respectively. The $2 \mathrm{R}$ element in both sexes can be present in the following combinations: $2 \mathrm{R} / 2 \mathrm{R}, 2 \mathrm{R} / 2 \mathrm{R} 1$ and $2 \mathrm{R} 1 / 2 \mathrm{R} 1$ homozygous standard, heterozygous and homozygous inverted sequence, respectively. An. messeae species A and $\mathrm{B}$ have almost completely overlapping inversion polymorphisms and can be identified by inversions on sex chromosomes; they also differ quantitatively, by the frequencies of autosomal inversions [26,27]. If a specimen possesses a combination of $1 \mathrm{~L} 1 / 1 \mathrm{~L} 1,1 \mathrm{~L} / 1 \mathrm{~L} 1$ or $1 \mathrm{~L} 1 / \neg$ with the standard $2 \mathrm{R}$ version in its karyotype, it can be ascertained, with a probability close to 1 , that this specimen belongs to $A n$. messeae A. The variants $1 \mathrm{~L} / 1 \mathrm{~L} 1,1 \mathrm{~L} 1 / 1 \mathrm{~L} 1$ and $1 \mathrm{~L} 1 / \neg$ almost never occur in the karyotype of $A n$. messeae B. 2R/2R1 heterozygotes and 2R1/2R1 homozygotes almost always belong to $A n$. messeae B [26,27]. The results of cytogenetic analysis of $A n$. messeae s.l. populations are summarized in Table 2. The frequencies of homozygotes 1L1/1L1 and heterozygotes 1L/1L1 (calculated in subpopulations of females and shown together), and homozygous $2 \mathrm{R} / 2 \mathrm{R}$ allow us to determine the approximate proportions of $A n$. messeae A 
Table 1 Species composition of Anopheles samples

\begin{tabular}{|c|c|c|c|c|}
\hline \multirow[t]{2}{*}{ Collection localities (coordinates) } & \multirow{2}{*}{$\begin{array}{l}\text { Collection } \\
\text { date }\end{array}$} & \multicolumn{3}{|c|}{ Number of specimens/An. species } \\
\hline & & maculipennis & messeae s.l. & beklemishevi \\
\hline 1 Rybinsk $\left(58^{\circ} 03^{\prime} \mathrm{N} ; 38^{\circ} 50^{\prime} \mathrm{E}\right)^{*}$ & 25.06 .87 & 0 & 96 & 0 \\
\hline 2 Yaroslavl $\left(57^{\circ} 37^{\prime} \mathrm{N} ; 39^{\circ} 51^{\prime} \mathrm{E}\right)^{*}$ & 15.07.87 & 0 & 88 & 0 \\
\hline 3 Rostov $-1\left(57^{\circ} 11^{\prime} \mathrm{N} ; 38^{\circ} 24^{\prime} \mathrm{E}\right)$ & 21.07 .87 & 0 & 165 & 0 \\
\hline Rostov $-1^{*}$ & 24.07 .87 & 3 & 140 & 0 \\
\hline Rostov $-2^{*}$ & 20.08 .87 & 5 & 118 & 0 \\
\hline 4 Solnechnogorsk $\left(56^{\circ} 11^{\prime} \mathrm{N} ; 36^{\circ} 59^{\prime} \mathrm{E}\right)^{*}$ & 02.06 .79 & 44 & 77 & 1 \\
\hline Solnechnogorsk & 30.08 .79 & 45 & 56 & 0 \\
\hline Solnechnogorsk & 09.06 .81 & 16 & 57 & 0 \\
\hline Solnechnogorsk & 09.07 .81 & 9 & 87 & 0 \\
\hline Solnechnogorsk & 30.08 .81 & 14 & 14 & 0 \\
\hline 5 Suzdal $\left(56^{\circ} 26^{\prime} \mathrm{N} ; 40^{\circ} 26^{\prime} \mathrm{E}\right)^{*}$ & 02.06 .79 & 6 & 28 & 2 \\
\hline 6 Protvino, $54^{\circ} 52^{\prime} \mathrm{N} ; 37^{\circ} 13^{\prime} \mathrm{E}$ & 10.06 .81 & 60 & 9 & 0 \\
\hline Protvino* & 08.07 .81 & 52 & 24 & 0 \\
\hline Protvino* & 28.08 .81 & 58 & 79 & 0 \\
\hline 7 Murom $\left(55^{\circ} 34^{\prime} \mathrm{N} ; 42^{\circ} 02^{\prime} \mathrm{E}\right)^{*}$ & 28.08 .86 & 81 & 5 & 0 \\
\hline 8 Verbovskii $\left(55^{\circ} 31^{\prime} \mathrm{N} ; 41^{\circ} 59^{\prime} \mathrm{E}\right)^{*}$ & 27.08 .86 & 10 & 190 & 2 \\
\hline 9 Yoshkar-Ola $\left(56^{\circ} 38^{\prime} \mathrm{N} ; 47^{\circ} 53^{\prime} \mathrm{E}\right)^{*}$ & 02.09 .86 & 2 & 178 & 0 \\
\hline 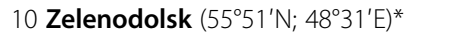 & 07.08.73 & 0 & 118 & 1 \\
\hline Zelenodolsk ${ }^{*}$ & 04.06.79 & 2 & 15 & 0 \\
\hline 11 Samara $\left(53^{\circ} 11^{\prime} \mathrm{N} ; 50^{\circ} 07^{\prime} \mathrm{E}\right)^{*}$ & 10.09 .86 & 23 & 108 & 0 \\
\hline 12 Yablonovsky $\left(44^{\circ} 55^{\prime} \mathrm{N} ; 38^{\circ} 56^{\prime} \mathrm{E}\right)$ & 27.08 .81 & 0 & 78 & 0 \\
\hline 13 Khadyzhensk $\left(44^{\circ} 26^{\prime} \mathrm{N} ; 39^{\circ} 22^{\prime} \mathrm{E}\right) \mathrm{LD}$ & 26.08 .81 & 59 & 36 & 0 \\
\hline Khadyzhensk HD & 26.08 .81 & 86 & 26 & 0 \\
\hline 14 Kharkov $\left(50^{\circ} 00^{\prime} \mathrm{N} ; 36^{\circ} 13^{\prime} \mathrm{E}\right)$ & 22.08 .98 & 93 & 18 & 0 \\
\hline 15 Kundravy $\left(54^{\circ} 50^{\prime} \mathrm{N} ; 60^{\circ} 13^{\prime} \mathrm{E}\right)$ & 16.09 .81 & 0 & 100 & 0 \\
\hline 16 Miass- $1\left(55^{\circ} 01^{\prime} \mathrm{N} ; 60^{\circ} 06^{\prime} \mathrm{E}\right)$ & 10.08 .99 & 0 & 124 & 0 \\
\hline Miass-2 $\left(55^{\circ} 00^{\prime} \mathrm{N} ; 60^{\circ} 04^{\prime} \mathrm{E}\right)$ & 12.08 .99 & 0 & 126 & 0 \\
\hline Miass-1 & 25.08 .00 & 0 & 157 & 0 \\
\hline Miass-1 & 26.08 .10 & 1 & 137 & 0 \\
\hline Miass-1 & 16.08 .11 & 2 & 28 & 0 \\
\hline Miass-3 $\left(55^{\circ} 02^{\prime} \mathrm{N} ; 60^{\circ} 06^{\prime} \mathrm{E}\right)$ & 17.08 .11 & 4 & 76 & 0 \\
\hline Miass-1 & 14.08 .12 & 5 & 139 & 0 \\
\hline Miass-3 & 16.08 .12 & 0 & 47 & 0 \\
\hline Miass- $4\left(54^{\circ} 58^{\prime} \mathrm{N} ; 60^{\circ} 05^{\prime} \mathrm{E}\right)$ & 20.08 .12 & 0 & 101 & 0 \\
\hline 17 Ozernoe $\left(53^{\circ} 27^{\prime} \mathrm{N} ; 58^{\circ} 47^{\prime} \mathrm{E}\right)$ & 15.08 .12 & 2 & 6 & 0 \\
\hline 18 Koltashi $\left(57^{\circ} 24^{\prime} \mathrm{N} ; 60^{\circ} 52^{\prime} \mathrm{E}\right)$ & 05.07.12 & 0 & 112 & 3 \\
\hline Koltashi & 11.07.12 & 0 & 91 & 12 \\
\hline
\end{tabular}

Note: * - published previously [33]; LD and HD - low and high larval density, respectively (a three-fold difference).

in the populations studied. While the frequencies of homozygotes $2 \mathrm{R} 1 / 2 \mathrm{R} 1$ and heterozygotes $2 \mathrm{R} / 2 \mathrm{R} 1$ (so as for $2 \mathrm{R} / 2 \mathrm{R}$ calculated in whole populations and shown together) allow us to estimate the proportions of $A n$. messeae B. Thus, analysis of polytene chromosomes allows species identification only for those specimens which possess marker combinations of chromosome variants in their karyotype. An. messeae species A and B can be accurately identified by the taxonoprint analysis [27] or by patterns of PCR product digestion of the ITS2 
Table 2 Dynamics of chromosome variants in An. messeae s.l., depending on the presence and relative abundance of An. maculipennis

\begin{tabular}{|c|c|c|c|c|c|}
\hline \multirow{2}{*}{$\begin{array}{l}\text { Collection localities } \\
\text { and dates }\end{array}$} & \multirow[t]{2}{*}{$\mathbf{N}$} & \multirow{2}{*}{$\begin{array}{l}\text { An. maculipennis } \\
\text { frequency }(\%)\end{array}$} & \multicolumn{3}{|c|}{ Frequency of chromosome variants in An. messeae s.l. (\%) } \\
\hline & & & 1L/1L1, 1L1/1L1 & $2 \mathrm{R} / 2 \mathrm{R}$ & 2R/2R1, 2R1/2R1 \\
\hline Rybinsk (25.06.87) & $96 \mathrm{lV}$ & 0 & $86.5 \pm 4.7$ & $63.5 \pm 4.9$ & $36.5 \pm 4.9$ \\
\hline Yaroslavl (15.07.87) & $88 \mathrm{lv}$ & 0 & $56.2 \pm 7.2$ & $60.2 \pm 5.2$ & $39.8 \pm 5.2$ \\
\hline Rostov-1 (21.07.87) & $165 \mathrm{lv}$ & 0 & $73.0 \pm 4.7$ & $61.2 \pm 3.8$ & $38.8 \pm 3.8$ \\
\hline Rostov-1 (24.07.87) & $143 \mathrm{lv}$ & $2.1 \pm 1.2$ & $85.9 \pm 3.8$ & $77.9 \pm 3.5$ & $22.1 \pm 3.5$ \\
\hline Rostov-2 (20.08.87) & $123 \mathrm{lV}$ & $4.1 \pm 1.9$ & $54.8 \pm 5.8$ & $62.7 \pm 4.5$ & $37.3 \pm 4.5$ \\
\hline Solnechnogorsk (02.06.79) & $122 \mathrm{f}$ & $36.1 \pm 4.3$ & $20.8 \pm 4.6$ & $35.1 \pm 5.4$ & $64.9 \pm 5.4$ \\
\hline Solnechnogorsk (09.06.81) & $73 f$ & $21.9 \pm 4.8$ & $44.8 \pm 6.6$ & $55.3 \pm 6.6$ & $44.7 \pm 6.6$ \\
\hline Solnechnogorsk (09.07.81) & $96 f$ & $9.4 \pm 3.0$ & $42.5 \pm 5.3$ & $51.7 \pm 5.4$ & $48.3 \pm 5.4$ \\
\hline Solnechnogorsk (30.08.81) & $28 \mathrm{f}$ & $50.0 \pm 9.4$ & $14.3 \pm 9.4$ & $35.7 \pm 12.8$ & $64.3 \pm 12.8$ \\
\hline Suzdal (02.06.79) & $36 f$ & $16.7 \pm 6.2$ & $17.8 \pm 7.2$ & $3.6 \pm 3.5$ & $96.4 \pm 3.5$ \\
\hline Protvino (28.08.81) & $137 \mathrm{fd}$ & $42.3 \pm 4.2$ & $17.8 \pm 4.3$ & $67.1 \pm 5.3$ & $32.9 \pm 5.3$ \\
\hline Verbovskii (27.08.86) & $202 \mathrm{lv}$ & $5.0 \pm 1.5$ & $7.7 \pm 2.6$ & $51.6 \pm 3.6$ & $48.4 \pm 3.6$ \\
\hline Yoshkar-Ola (02.09.86) & $180 \mathrm{lv}$ & $1.1 \pm 0.8$ & $2.4 \pm 1.4$ & $34.1 \pm 3.6$ & $65.9 \pm 3.6$ \\
\hline Zelenodolsk (07.08.73) & $119 \mathrm{lv}$ & 0 & $1.0 \pm 1.1$ & $43.2 \pm 4.6$ & $56.8 \pm 4.6$ \\
\hline Samara (10.09.86) & $131 \mathrm{lv}$ & $17.6 \pm 3.3$ & $9.4 \pm 4.0$ & $96.3 \pm 1.8$ & $3.7 \pm 1.8$ \\
\hline Yablonovsky (27.08.81) & $78 \mathrm{lv}$ & 0 & $70.0 \pm 7.2$ & 100 & 0 \\
\hline Khadyzhensk (26.08.81), LD & $95 \mathrm{lV}$ & $62.1 \pm 5.0$ & $71.4 \pm 9.9$ & 100 & 0 \\
\hline Khadyzhensk (26.08.81), HD & $112 \mathrm{lv}$ & $76.8 \pm 4.0$ & $57.1 \pm 13.2$ & 100 & 0 \\
\hline Kundravy (16.09.81) & $100 \mathrm{fd}$ & 0 & $76.0 \pm 4.3$ & $95.0 \pm 2.2$ & $5.0 \pm 2.2$ \\
\hline Miass-1 (10.08.99) & $124 \mathrm{IV}$ & 0 & $56.3 \pm 6.2$ & $87.9 \pm 2.9$ & $12.1 \pm 2.9$ \\
\hline Miass-2 (12.08.99) & $126 \mathrm{lv}$ & 0 & $58.1 \pm 6.3$ & $90.5 \pm 2.6$ & $9.5 \pm 2.6$ \\
\hline Miass-1 (25.08.00) & $157 \mathrm{lV}$ & 0 & $61.8 \pm 4.8$ & $95.5 \pm 1.7$ & $4.5 \pm 1.7$ \\
\hline Miass-1 (26.08.10) & $138 \mathrm{lv}$ & $0.7 \pm 0.7$ & $44.9 \pm 5.6$ & $89.8 \pm 2.6$ & $10.2 \pm 2.6$ \\
\hline Miass-1 (16.08.11) & $30 \mathrm{lv}$ & $6.7 \pm 4.6$ & $40.0 \pm 12.6$ & $85.7 \pm 6.6$ & $14.3 \pm 6.6$ \\
\hline Miass-3 (17.08.11) & $80 \mathrm{lv}$ & $5.0 \pm 2.4$ & $19.1 \pm 6.1$ & $81.6 \pm 4.4$ & $18.4 \pm 4.4$ \\
\hline Miass-1 (14.08.12) & $144 \mathrm{IV}$ & $3.5 \pm 1.5$ & $34.2 \pm 5.3$ & $79.9 \pm 3.4$ & $20.1 \pm 3.4$ \\
\hline Miass-3 (16.08.12) & $47 \mathrm{lV}$ & 0 & $33.3 \pm 8.6$ & $91.5 \pm 4.1$ & $8.5 \pm 4.1$ \\
\hline Miass-4 (20.08.12) & $101 \mathrm{lV}$ & 0 & $32.1 \pm 6.4$ & $79.2 \pm 4.0$ & $20.8 \pm 4.0$ \\
\hline Koltashi (05.07.12) & $115 \mathrm{lV}$ & 0 & $42.1 \pm 6.5$ & $62.5 \pm 4.6$ & $37.5 \pm 4.6$ \\
\hline Koltashi (11.07.12) & $103 \mathrm{lv}$ & 0 & $40.5 \pm 6.3$ & $51.6 \pm 5.2$ & $40.4 \pm 5.2$ \\
\hline
\end{tabular}

Note: Iv - larvae, $\mathrm{f}$ - breeding females, $\mathrm{fd}$ - females in diapause; $\mathrm{N}$ - sample size; standard deviation is given as a measure of statistical error.

by the BstF5I restriction enzyme [30,35]. The identities of 102 An. messeae s.l. specimens collected in Miass in 2012 were established by ITS2 PCR-RFLP.

\section{Results and discussion}

Analysis of species composition from different regions and years (Table 1) revealed the following:

1) The proportion of An. maculipennis in samples collected at approximately the same time increased from the north and east to the south and west, and ranged from $0 \%$ in the Middle Urals to $80 \%$ in the North Caucasus and the Ukraine.

2) An. beklemishevi was identified in the samples collected mostly in the northern and eastern regions, and its peak frequency was detected at the extreme northeastern location (Koltashi, $80 \mathrm{~km}$ north of Yekaterinburg, the Rezh river backwater).

3) The proportions of sibling species may differ in samples collected simultaneously in closely situated locations, yet from different biotopes (An. maculipennis and An. messeae in Yablonovsky 
and Khadyzhensk, Murom and Verbovsky); they also can fluctuate significantly during the same breeding season and even over several days within the same location and biotope (Solnechnogorsk, Protvino, Rostov, Koltashi).

4) In eastern regions (Zelenodolsk, Miass), An. maculipennis was absent in the earlier samples, but present in samples collected several years later.

5) An. maculipennis, An. messeae s.l. and An. beklemishevi may reside in the same biotope, as may $A n$. maculipennis and $A n$. messeae s.l. or An. messeae s.l. and An. beklemishevi; however, An. maculipennis and An. beklemishevi do not occur together in the absence of $A n$. messeae s.l.

Elements of these observations are in agreement and show ecological diversification of the species at different stages of individual development. In particular, combinations of co-inhabiting species indicate that the ecological niche of $A n$. messeae s.l. is the widest among species studied. Borders of areas occupied by An. maculipennis and An. beklemishevi most likely reflect their responses to abiotic factors, which are commonly changing geographically. Furthermore, competition between the latter two species during larval development is higher compared to competition of each of them with $A n$. messeae s.l.

Analysis of mosquito larvae collected in different parts of the Pshish river backwaters, spaced by $5-6 \mathrm{~m}$ and characterized by variable population density (Table 2, Hadyzhensk), shows a prevalence of An. maculipennis in both zones, with a significantly higher proportion in the area with a higher population density $(\mathrm{p}<0.05)$. This could be interpreted as a result of species-specificity in egg-laying sites of $A n$. maculipennis that can give rise to microlocalities with higher density of this particular species. Another plausible scenario is active larval migration in accordance with ecological preferences. In either case, the specificity of distribution is due to the behavioral characteristics. The key factor here is how behavioral reactions of each species reflect its competing abilities. It was experimentally shown that, at least under laboratory conditions, if maintained together at a high density, larval survival of $A n$. maculipennis is superior to that of both $A n$. messeae s.l. and An. beklemishevi [36]. A similar situation can be expected to occur in natural habitats. Therefore, in cases of natural co-habitation, despite a high tolerance of $A n$. maculipennis and An. messeae s.l. larvae to water composition (both are found in the brackish water of Lake Muldakkul), An. maculipennis can outcompete under optimal combination of other abiotic factors. However, the species that loses in the larval competition is still able to use atypical habitats with extreme conditions. Thus, in the waters of drainage canals from rice fields in Yablonovsky village (Ciscaucasia, a region where $A n$. maculipennis is predominant), characterized by high saprobity and a high density of amphibians, only $A n$. messeae s.l. larvae, although at an extremely low density, were found. In addition, abiotic factors, which can compensate for inferior survival of a species at the larval stage by increasing its survival at the imago stage, may favor species coexistence in certain territories. An increase in the proportion of An. maculipennis in the southwest and south, generally coinciding with the isotherms of the warm time of the year and shorter periods of cold weather, indicates the primary role of temperature (through both direct and indirect effects) in determining the outcome of interactions between the species. This is in agreement with an idea proposed by Ushakov [37], according to which, two closely related species are characterized by discrete differences in the thermal stability of cells, in line with the temperature of their habitat. In other words, speciation is usually associated with adaptation at the cell rather than organismal level. Indeed, malaria research institutions reported, using direct measurements, that An. maculipennis females start leaving their wintering eustatic shelters at an average daily temperature of $7.1^{\circ} \mathrm{C}$ [38], while for $A n$. messeae s.l. this index was $4-5.0^{\circ} \mathrm{C}$ $[39,40]$. Discrete differences between species in their reaction to temperature, in particular, a later outfly from wintering shelters of $A n$. maculipennis females, delay the start of reproduction phase and apparently shift generations of species relative to each other. In the samples, this shift would manifest as an increase in the proportion of one of the species.

In line with temperature trends in northern Eurasia over the last 40 years, the distribution area of An. maculipennis s.s. was likely to have been expanding to the northeast previously as well, as was reported in 1989 [34]. However, this process was not accurately recorded at its early stage. Up to 1980 s, when $A n$. maculipennis s.s. was detected in Rostov, Suzdal, Murom, Yoshkar-Ola, Zelenodolsk and Samara using cytogenetic approach [34], the species was not observed in the region. Systematic studies carried out in Miass documented the emergence of An. maculipennis s.s. in the region. In 1999 and 2000, representative samples of Anopheles mosquito larvae collected in two ecologically distinct reservoirs in Miass were free from An. maculipennis (Table 1). In 2010, 2011 and 2012, several specimens from larval samples collected in these locations were identified as $A n$. maculipennis. Despite the frequency of $A n$. maculipennis, larvae are still low (up to $7 \%$ in some samples and absent in others), this species was found in a number of ecologically distinct habitats and in different years, therefore, its presence in Miass and consequently in the South Urals is now confirmed. The study of samples collected in Lake Muldakkul and in Koltashi village in 2012 revealed the presence of $A n$. maculipennis in the first 
location and absence in the second, where An. beklemishevi was found.

Of note, in Miass, An. maculipennis was first identified in 2010 with a frequency similar to that reported for the northeast periphery of this species area in 1986-1987. Its low frequency in different biotopes suggests that it most likely emerged in Miass in 2008 or 2009. This allows estimating the rate of An. maculipennis expansion to the east.

Given that the time of sample collection in the eastern locality for the earlier study (Samara, City Park, 1986) and the most probable time when An. maculipennis appeared in Miass are separated by 22 years and about $750 \mathrm{~km}$, and assuming that the border of the distribution area at that time was already shifted to the east of Samara, the average speed of the border movement eastwards is about $30 \mathrm{~km}$ per year. If true, this speed is significantly higher than estimated for other insect species, - $16.9 \mathrm{~km}$ per decade [24]. Because An. maculipennis is an endophilic species [41,42], its expansion involves migration between populated places. Its endophilic nature and the possibility of passive mosquito migration in cars, trains and aircrafts is the most likely cause of rapid expansion of its distribution area. The territories between the Volga and the Southern Urals, although likely in patches, have already been invaded by An. maculipennis, and the vector of its expansion is from urban areas to the countryside. Taking into account the key role of temperature in the life cycle of mosquitoes and isothermal patterns in the European part of Russia and the Urals, the northern border of the An. maculipennis habitat is likely to move at the same speed, about 600-700 $\mathrm{km}$ further to the north of the border reported in 19861987 [34]. Moskaev (2012) [22] and Perevozkin et al. (2012) [28] found An. maculipennis s.s. in Karelia up to

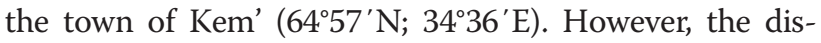
tance between Rostov, where An. maculipennis at low frequency was discovered in 1986, and Kem' is over 1000 $\mathrm{km}$. In the literature, there is also a discrepancy in the description of the species composition in Kem', where, according to Moskaev [22], all three species are present, while Perevozkin et al. [28] found only An. maculipennis and An. beklemishevi. Neither Stegnii et al. [14], nor Moskaev [22], nor the authors of the present study have detected the coexistence of An. maculipennis and An. beklemishevi in the absence of An. messeae s.l. in any of the geographical locations studied. Based on the data available so far, it can be assumed that the probable northern border of An. maculipennis habitat lies at a latitude of $64^{\circ}$ $\mathrm{N}$, i.e. to the north of the town of Segezha.

Species-specific responses of adult mosquitoes to temperature regimens [38-40], species competition at the larval stage of development [36], and patterns of their geographical distribution [15,16,41] suggest that the expansion of An. maculipennis to the north and east is a part of the biocenotic process caused by global warming. Changes in the borders of distribution areas and/or proportions of sibling species in the zones where the species are sympatric are also components of this process. The rate of climate warming has been estimated at $0.5^{\circ} \mathrm{C}$ per 100 years in the northern parts of European Russia and $1.4-1.6^{\circ} \mathrm{C}$ per 100 years in the south of the Urals, with the largest incremental changes in the past several decades [3]. One consequence of climate warming is an extension of reproductive period and shortening of hibernation period for mosquitoes. Thus, more thermophilic and less vulnerable An. maculipennis is given a better opportunity to invade the regions adjacent to the northern and eastern borders of its current distribution area. Expansion of An. maculipennis to the northeast is accompanied by a decrease in An. messeae s.l. and $A n$. beklemishevi frequencies and probably even disappearance of the latter species. An. beklemishevi was found in the surroundings of Priozersk, Syktyvkar and Chelyabinsk in 1975 [14]. However, in the present study this species was absent in the samples collected in 1981 and 1999 in the region of Chelyabinsk (Kundravy, Miass) (Table 1). It should be noted that the samples from Kundravy village consisted of females in diapause, among which specimens of the exophilic An. beklemishevi could be absent due to environmental and behavioral characteristics of this species. Moskaev (2012) [22] did not find An. beklemishevi in Priozersk and confirmed its lower frequency in Syktyvkar in 2010 compared to the report of Stegnii et al. in 1978 [14]. Previously noted disappearance of An. beklemishevi in Zelenodolsk coincided with the emergence of $A n$. maculipennis [34]. Steady climate change and foreseeable responses of the species studied allow predicting future events. Considering that most settlements to the east of the Urals are situated along the Trans-Siberian Railway and taking into account the endophily of An. maculipen$n i s$, this species will expand to the east within borders very similar to that of An. messeae A [27], i.e. as a gradually narrowing stripe of 300-400 km wide, with the borders lying in the south of the forest and the north of the foreststeppe zones. Obviously, the speed of a species expansion will depend on the temperature dynamics in the region. It is important to evaluate possible consequences of the growing degree of overlap between the distribution areas of An. maculipennis and both cryptic species of $A n$. messeae s.l., as well as increasing contacts between $A n$. maculipennis and An. beklemishevi. At the larval stage, under conditions of high-density, An. maculipennis demonstrates superior survival compared to An. messeae s.l., i.e. both A and B species [36]. An. messeae A and $A n$. maculipennis are considered as endophilic species, while An. messeae B is exophilic [20]. Therefore, An. maculipennis and $A n$. messeae A have very similar environmental needs, and their ecological niches largely overlap, leading 
to their competition and as a result, reduction in the frequency of the latter species. Indeed, cytogenetic analysis showed that $A n$. maculipennis emergence in Miass was accompanied by a change in the proportions of the $A n$. messeae cryptic species. In line with this finding, we detected a highly significant $(\mathrm{p}<0.001)$ decrease in the frequencies of homozygotes, heterozygotes and hemizygotes for inversion 1L1, as well as other cytogenetic markers of An. messeae A, over the period from 1999 to 2011, accompanied by a corresponding increase in the frequencies of markers typical for the $A n$. messeae $\mathrm{B}$ (Table 2). In addition, a reliable cytogenetic marker of $A n$. messeae $\mathrm{B}$, the inversion 1L2 on the sex chromosome, reached a detectable frequency in the region. The 2011 sample from location 'Miass-1' contained 2 heterozygous females and 1 hemizygous male for this inversion out of 76 An. messeae s.l. specimens. Proportions of the A and B species and frequencies of marker $1 \mathrm{~L}$ chromosome variants in $A n$. messeae A were determined in the samples collected in 2012 using ITS2 PCR-RFLP (Table 3). Species identification was performed for $102 \mathrm{An}$. messeae s.l. specimens (32 females and 24 males of $A n$. messeae A and 28 females and 18 males of $A n$. messeae B), for these the presence of the inversions on X-chromosome was also determined. Only one male, identified by ITS2 PCR-RFLP as belonging to $A n$. messeae $\mathrm{B}$, had variant $1 \mathrm{~L} 1 / \neg$. Thus, the inversion $1 \mathrm{~L} 1$ is highly specific for $A n$. messeae A (provided that the inversions $1 \mathrm{~L} 1$ are identical in both cryptic species, and the latter not fully proven yet [27]). Thus, a significant increase in the proportion of $A n$. messeae $\mathrm{B}$ $(\mathrm{p}<0.01)$ from earlier to later samples, as defined based on marker inversion variants, reflects the actual sequence of events. This allows us to estimate the proportions of An. messeae cryptic species A and B by analyzing the frequencies of the above cytogenetic markers in other regions and locations. Analysis of species proportions in different geographic locations (Table 2) showed an increase

Table 3 The composition of chromosome arm $1 \mathrm{~L}$ variants in An. messeae A and B (after species identification of larvae by ITS2 PCR-RFLP; Miass, 2012)

\begin{tabular}{|c|c|c|c|c|c|c|}
\hline \multirow{2}{*}{$\begin{array}{l}\text { Species } \\
\text { Variants }\end{array}$} & \multicolumn{2}{|c|}{ An. messeae A } & \multicolumn{2}{|c|}{ An. messeae B } & \multicolumn{2}{|c|}{ An. messeae s.l. } \\
\hline & $\mathbf{N}$ & $f(\%)$ & $\mathbf{N}$ & $f(\%)$ & $\mathbf{N}$ & $f(\%)$ \\
\hline $1 \mathrm{~L} / 1 \mathrm{~L}$ & 16 & $50.0 \pm 8.8$ & 28 & 100 & 44 & $73.3 \pm 5.7$ \\
\hline 1L/1L1 & 11 & $34.4 \pm 8.4$ & 0 & 0 & 11 & $18.3 \pm 5.0$ \\
\hline $1 \mathrm{~L} 1 / 1 \mathrm{~L} 1$ & 5 & $15.6 \pm 6.4$ & 0 & 0 & 5 & $8.3 \pm 3.6$ \\
\hline Total females & 32 & 100 & 28 & 100 & 60 & 99.9 \\
\hline $1 \mathrm{~L} / \neg$ & 16 & $66.7 \pm 9.6$ & 17 & $94.4 \pm 5.4$ & 33 & $78.6 \pm 6.3$ \\
\hline 1L1/ᄀ & 8 & $33.3 \pm 9.6$ & 1 & $5.6 \pm 5.4$ & 9 & $21.4 \pm 6.3$ \\
\hline Total males & 24 & 100 & 18 & 100 & 42 & 100 \\
\hline Total individuals & 56 & $54,9 \pm 4,9$ & 46 & $45,1 \pm 4,9$ & 102 & 100 \\
\hline
\end{tabular}

Note: $\mathrm{N}$ - sample size; standard deviation is given as a measure of statistical error. in the frequency of cytogenetic markers typical for $A n$. messeae $\mathrm{B}$ in those instances when An. maculipennis simultaneously occurs in this area or when its frequency is increased.

For example, in Solnechnogorsk, Suzdal, and Protvino where the proportion of An. maculipennis is high or it is dominant over other species, the frequency of the cytogenetic markers typical for $A n$. messeae $\mathrm{B}$ is relatively high. However, in areas where An. maculipennis is absent or rare, the proportion of $A n$. messeae A is increased, which is signaled by high frequencies of chromosome variants typical for this species (Rybinsk, Yaroslavl and Rostov). In some regions this correlation is not observed (Yoshkar-Ola), which is likely due to the low numbers of $A n$. messeae A individuals in this region. In Ciscaucasia and in the suburbs of Kharkov, in accordance with its cytogenetic structure, only An. messeae A was found in conjunction with An. maculipennis. In Khadyzhensk and in the suburbs of Kharkov, the latter species was predominant (Table 2). Despite significant $(\mathrm{p}<0.05)$ differences in the proportions of species between the samples from Khadyzhensk and Kharkov, differences in the frequencies of $1 \mathrm{~L} / 1 \mathrm{~L} 1,1 \mathrm{~L} 1 / 1 \mathrm{~L} 1$ and several other variants were not detected. Thus, in the competition with other species, $A n$. messeae A behaves as a whole, without showing any significant advantages for carriers of specific inversions and their combinations. This means that cytogenetic changes of $A n$. messeae s.l. larvae in Miass, which occurred after the appearance of $A n$. maculipennis, were due to a change in the frequencies of these species rather than a change of inversion frequencies in the cryptic species. A finding which was unexpected and will require further studies was a decrease in the proportion of $A n$. messeae A in Miass given a low presence (up to $7 \%$ ) of $A n$. maculipennis. It is also possible that the observed trends in species frequencies result from not only competition between An. maculipennis s.l. species, but also from alterations in other ecosystem components. Our results describing the impact of An. maculipennis on the ratio of An. messeae species A and $\mathrm{B}$ are consistent with the situation described in Germany, where An. messeae s.l. and An. maculipennis are sympatric. According to the results of sequencing of marker portions of genomic DNA from mosquitoes collected in localities with low (a few percent) and high (over 50\%) occurrence of An. maculipennis, An. messeae species referred here as the species $B$, outnumbered the other one [43].

Possible consequences of $A n$. maculipennis expansion to the Urals, and likely, soon after that, to Western Siberia can be foreseen. In parallel with a decrease in the number of $A n$. messeae s.l., the proportion of An. messeae A cryptic species will also decline, together with a respective increase for $A n$. messeae B. The latter will manifest itself through increasing karyotype variability, 
i.e. a process opposite of that previously described [20]. Thus, An. maculipennis will follow the path of colonization of Siberia pursued earlier by $A n$. messeae A, which is characterized by similar environmental needs but is somewhat more resistant to low temperatures. Expansion of An. maculipennis to the north and east will continue until an equilibrium is achieved among the four species, two of which (An. maculipennis and $A n$. messeae A) are endophilic and thermophilic and the other two (An. messeae B and An. beklemishevi) are exophilic and cold-resistant. This balance will be maintained mainly due to different durations of the reproductive period typical for each species, during which a growth in the frequencies of the first two species is expected, and this growth will be more pronounced for An. maculipennis. The second factor to play a role will be the availability of wintertime eustatic shelters and temperature in those during the cold time of the year, when the numbers of the first two species will decline more rapidly. These conditions will be less severe for a more cold-resistant $A n$. messeae A compared to An. maculipennis. Expansion of An. maculipennis is likely to be accompanied by ousting of $A n$. beklemishevi from more or less populated areas, and correspondingly, the southern and western borders of the distribution area of the latter species will move to the north and east. However, because An. beklemishevi is exophilic, it will still be able to survive, although in small quantities, in the wild. Given that An. maculipennis is able to transfer Plasmodium vivax, and that global warming leads to increased species diversity and abundance of Anopheles on large territories, one can confirm a worsening epidemiological situation in Eurasia.

Results of the present study and previously published data on An. maculipennis geographic and temporal distribution made it possible to reconstruct the dynamics of the area occupied by the species (Figure 1). White (1978) [15]

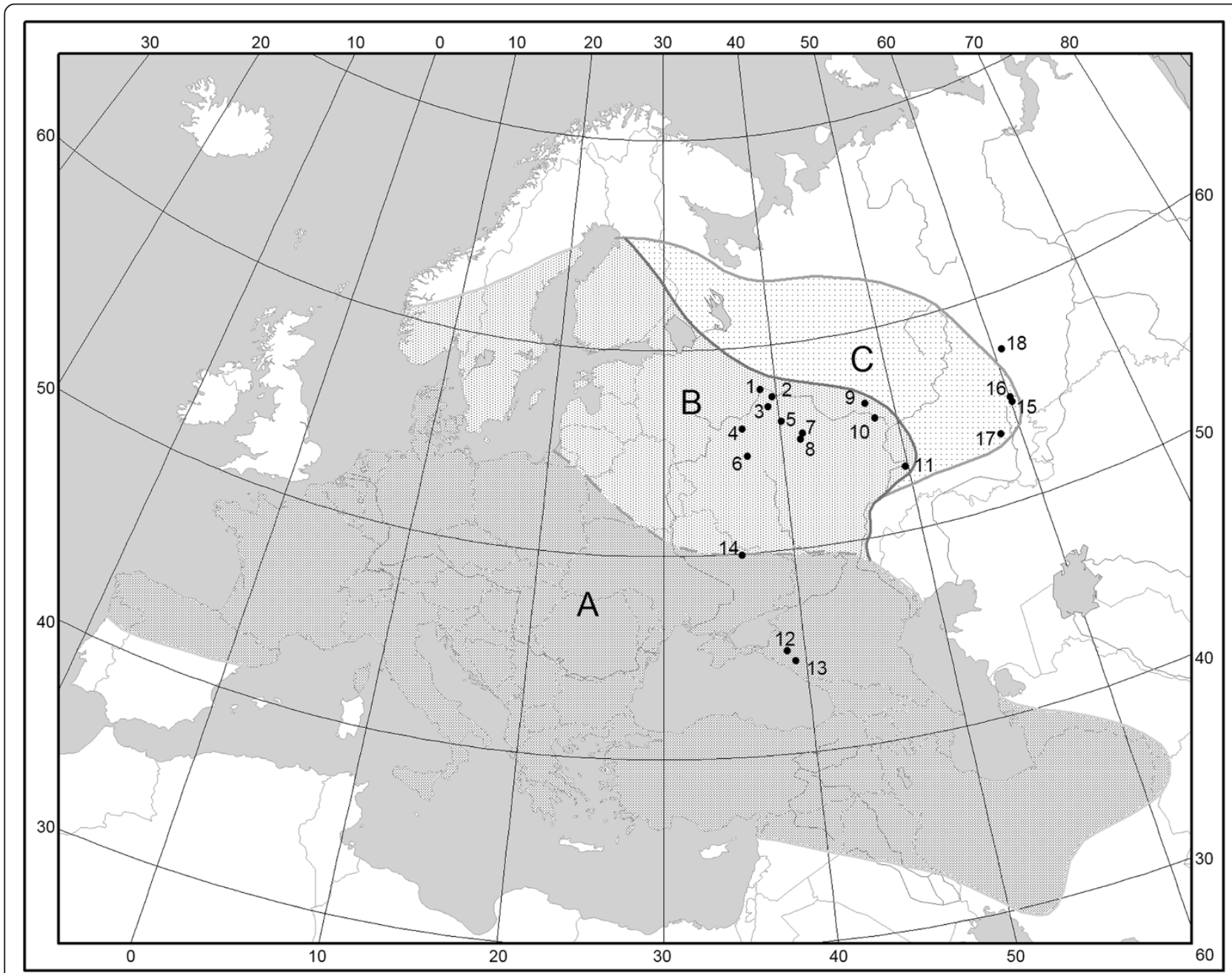

Figure 1 Dynamics of An. maculipennis distribution area: A - An. maculipennis distribution area described by White (1978) [15], B - by Novikov, Alekseev (1989) [34], with the additions by Ramsdale and Snow (2000) [45] for Scandinavia and Ciscaucasia; C - the expansion of the area from 1986 to 2010. Locations have the same numbers as in Table 1. 
and Novikov \& Alekseev (1989) [34] reported conflicting data on the northeastern border of its area (segment B in Figure 1). This can be explained by the expansion of $A n$. maculipennis to the northeast and by the limited information available at the time White's review was prepared. Our results favor the former explanation for this discrepancy. Expansion of the distribution area during the period from 1986 to 2010 (segment C in Figure 1) can be ascertained based on our results and the results of other researchers $[22,28]$. Due to lack of detailed data on Anopheles distribution in Scandinavia [44], the borders of its distribution area in this region were determined based on data provided by Ramsdale \& Snow [45]. The southeastern borders reported by White (1978) [15] have been confirmed by recent studies. In Iran, An. maculipennis was found from the southeastern shore of the Caspian Sea to settlements located to the northeast of the Persian Gulf [46]. An. maculipennis was also found in Turkey, Iraq and Syria, but not in Tajikistan and Afghanistan $[47,48]$.

\section{Conclusions}

Significant increase in the global temperature, i.e. global warming, recorded in the past 40 years, has resulted in the changes of Maculipennis Complex species distribution in Eurasia. The distribution area of An. maculipennis s.s. is expanding to the northeast at an average speed of approximately $30 \mathrm{~km}$ per year; in 2008-2009 the species appeared in the Southern Urals. Colonization by An. maculipennis s.s. leads to a decrease in the frequency of $A n$. messeae s.l. and its cryptic species $A n$. messeae A, and a concomitant increase in the frequency of $A n$. messeae B. Likely, this is also accompanied by either active gradual ousting or passive disappearance of $A n$. beklemishevi. Ecologically, the above species, particularly An. maculipennis and An. beklemishevi, primarily differ in their responses to temperature. The latter is manifested in diversification of species over time, different rates of development during reproductive periods and differential resistance to low temperatures during overwintering. The ecological niches of An. maculipennis and $A n$. messeae A most considerably overlap, while for those of An. maculipennis and An. messeae-B only a minor degree of overlap is observed. Ecologically, An. maculipennis and $A n$. beklemishevi are very similar. However, they are sharply demarcated with respect to certain abiotic factors (mineral composition and temperature of water) whose dynamics would significantly modify the effect of all other factors. In the northeastern periphery of the An. maculipennis distribution area, sympatry with $A n$. messeae s.l. is compulsory, with An. beklemishevi - possible; coexistence of $A n$. maculipennis and An. beklemishevi in larval habitats in the absence of $A n$. messeae s.l. is an exception. On this territory, one can expect cyclic fluctuations both in the number and the frequency of An. maculipennis, with ups during the warm (reproductive) season and downs during wintertime.
Competing interests

The authors declare that they have no competing interests.

\section{Authors' contributions}

YuMN conceived the study; YuMN and OW collected the samples; YuMN performed cytogenetic analysis; OW performed PCR; YuMN and OW wrote the manuscript; YuMN and OW approved the final version of the manuscript.

\section{Acknowledgements}

We would like to thank Ms. Lubov' V Fedorova and Ms. Darya I Olyushina for their assistance in sample collection and Professor Helen Benes for discussions and critical reading of the manuscript. We are also grateful to Dr. Tatyana Shelkovnikova for correcting the English language of the final version of the manuscript.

This work was partially supported by a grant from the RAS Presidium program "Wildlife", project 30.33.

\section{Author details}

${ }^{1}$ Department of Cytology and Genetics of Tomsk State University, Tomsk, Russia. ${ }^{2}$ Institute of Cytology and Genetics SB RAS, Novosibirsk, Russia.

Received: 20 March 2014 Accepted: 14 August 2014

Published: 22 August 2014

\section{References}

1. WHO: Mosquitoes of the genus Anopheles in countries of the WHO European Region having faced a recent resurgence of malaria: Regional research project, 2003-2007. Copenhagen: WHO Regional Office for Europe; 2008.

2. WHO: World Malaria Report 2012. Geneva: World Health Organization; 2012

3. Anisimov OA, Lobanov VA, Reneva SA: Analysis of the changes in air temperature in Russia and empirical forecast for the first quarter of the $21^{\text {st }}$ century. Russ Meteorol Hydrol 2007, 32(10):620-626.

4. Manson P: Tropical diseases: a manual of the diseases of warm climates. London: Cassel and Co Ltd; 1898.

5. Snow K: Malaria and mosquitoes in Britain: the effect of global climate change. JEMCA (EMB) 1999, 4:17-25.

6. Alekseev AN: The influence of the global climate change on bloodsucking ectoparasites and the pathogens they transmit. Vestn Ros Akad Med Sci 2006, 3:21-25 [in Russian].

7. Bates M: The nomenclature and taxonomic status of the mosquitoes of the Anopheles maculipennis complex. Ann Entomol Soc Am 1940, 33:343-356.

8. Kitzmiller JB, Frizzi G, Baker RH: Evolution and speciation within the maculipennis complex of the genus Anopheles. In Genetics of Insect Vectors of Diesease. Edited by Wright JW, Pal R. Amsterdam: Elsevier Publ Co; 1967:151-210

9. Takken W, Geene R, Adam W, Jetten TH, van der Velden JA: Distribution and dynamics of larval populations of Anopheles messeae and An. atroparvus in the province of South Holland, The Netherlands. AMBIO 2002, 31(3):212-218.

10. Frizzi G: Salivary gland chromosomes of Anopheles. Nature 1947 160(4059):226-227

11. Frizzi G: Etude cytogenetique $\mathrm{d}^{\prime}$ Anopheles maculipennis en Italie. B World Health Organ 1953, 9:335-344.

12. Stegnii VN, Kabanova VM: Cytoecological study of indigenous populations of the malaria mosquito on the territory of the USSR. I. Identification of a new species of Anopheles in the Maculipennis Complex by the cytodiagnostic method. Mosa Syst 1978, 10(1):1-12.

13. Stegnii VN, Kabanova VM: Chromosomal analysis of the malaria mosquito species Anopheles atroparvus and An. maculipennis (Diptera, Culicidae). Zool Zh 1978, 57(4):613-619 [in Russian].

14. Stegnii VN, Novikov YuM, Kabanova VM: Cytogenetic analysis and distribution of the malaria mosquito Anopheles beklemishevi. Zool Zh 1978, 57(6):873-876 [in Russian].

15. White GB: Systematic reappraisal of the Anopheles maculipennis complex. Mosa Syst 1978, 10(1):13-44.

16. Stegnii VN: Evolutionary potencies of chromosomally monomorphic and polymorphic species. In Phenetics of populations. Moscow: 1982:112-118 [in Russian]. 
17. Markovich NYa: Biota response to climate warming in Europe. Med Parasitol i Parasitarn Bolezni 2003, (4):23-26 [in Russian].

18. Sergiev VP, Baranova AM, Markovich NYa, Supryaga VG, Ganushkina LA: Possible impact of the climate change on the spread of vector-borne diseases on the territory of Russia. In Climate change and health in Russia in XXI century. Moscow: Adamant Publ Ass; 2004:143-147 [in Russian].

19. Novikov YuM: The microevolution of the malaria mosquito Anopheles messeae population in Tomsk area over a nine-year period. In Young scientists and specialists - for national economy. Fourth regional scientific and practical conference, Biology. Tomsk: TSU Publ; 1983:31-32 [in Russian].

20. Novikov YuM: Effects of global warming: Directed dynamics of Anopheles species proportions and cytogenetic structure of the taxon Anopheles messeae Fall in Western Siberia. In Problems of evolutionary cytogenetics, selection and introduction. Materials of scientific readings dedicated to the 100th anniversary of Professor VP Chekhov. Tomsk: TPU Publ Co; 1997:39-41 [in Russian].

21. Novikov YuM: Global warming, distribution areas, proportion and inversion polymorphisms of the Anopheles species. In Problems of ecology. Reading in honor of the memory of Professor MM Kozhov. Irkutsk: ISU Publ; 2010:253 [in Russian].

22. Moskaev AV: Ecological differentiation of the malaria mosquito sibling species in European part of Russia. In Synop Dissert Degr Cand Biol Sci. Moscow; 2012,25 [in Russian].

23. Hickling R, Roy DB, Hill JK, Fox R, Thomas CD: The distributions of a wide range of taxonomic groups are expanding polewards. Glob Change Biol 2006, 12(3):450-455.

24. Chen I-C, Hill JK, Ohlemüller R, Roy DB, Thomas CD: Rapid range shifts of species associated with high levels of climate warming. Science 2011, 333(6045):1024-1026.

25. Musolin DL, Saulich AK: Responses of insects reactions to the current climate change: from physiology and behavior to range shifts. Entomol Obozr 2012, 91(1):3-35 [in Russian].

26. Novikov YuM: Anopheles messeae Fall. (Diptera, Culicidae) - two species in statu nascendi. In Macroevolution (materials of the 1st All-Union conference on evolutionary problems). Moscow: 'Science' Publ; 1984:13-14 [in Russian].

27. Novikov YuM, Shevchenko Al: Inversion polymorfism and the divergence of the two cryptic forms of Anopheles messeae (Diptera, Culicidae) at the level of genomic DNA repeats. Russ J Genet 2001, 37(7):754-763.

28. Perevozkin VP, Gordeev MI, Moskaev AV, Ahmetova NM, Bondarchuk SS: Inversion polymorphism and ecological differentiation of malaria mosquitoes (Diptera, Culicidae) in Karelia. Russ J Genet 2012, 48(7):679-683.

29. Nicolescu G, Linton Y-M, Vladimirescu A, Howard TM, Harbach RE: Mosquitoes of the Anopheles maculipennis group (Diptera: Culicidae) in Romania, with the discovery and formal recognition of a New species based on molecular and morphological evidence. B Entomol Res 2004, 94(6):525-535.

30. Vaulin OV, Novikov YuM: Geographical variability of ITS2 rDNA and COI mtDNA and the cryptic species of mosquito Anopheles messeae Fall. (Diptera: Culicidae). Inform Vestn VOGiS 2010, 14(3):546-557 [in Russian].

31. Kabanova VM, Kartashova NN, Stegnii VN: Study into the karyotypic structure of malaria mosquito natural populations in the Middle $\mathrm{Ob}^{\prime}$ region. Report I. Characteristics of the Anopheles maculipennis messeae karyotype. Tsitologiya 1972, 14(5):630-636 [in Russian].

32. Novikov YuM, Kabanova VM: Adaptive association of inversions in natural populations of the malaria mosquito Anopheles messeae Fall. Genetika 1979, 15(6):1033-1045 [in Russian].

33. Stegnii VN, Kabanova VM, Novikov YuM: Karyotypic study of the malaria mosquito. Tsitologiya 1976, 18(6):760-766 [in Russian].

34. Novikov YuM, Alexeev AN: On the NE border of the distribution area of Anopheles maculipennis and the SW border of the distribution area of An. beklemishevi. Med Parasitol i Parasitarn Bolezni 1989, 57(1):16-19 [in Russian].

35. Novikov YuM, Shevchenko Al, Vaulin OV: On the molecular genetic divergence of cryptic species of the Anopheles messeae taxon (Diptera, Culicidae) and phylogeny Maculipennis Complex. Vestn Tomsk U 2004, (10, Suppl):69-77 [in Russian].

36. Novikov YuM, Gordeev MI, Gadenova EV: Ecological differentiation of Anopheles messeae; An. maculipennis and An. beklemishevi larvae. Zool Zh 1983, 62(12):1818-1825 [in Russian].
37. Ushakov BP: On the labile and stable traits of the species. Vestn Lenin $U$ 1957, 4(21):153-154 [in Russian].

38. Avdeeva TJ, Zimin IA: Phenology of Anopheles maculipennis and the annual variation of malaria incidence in Abkhazia. In Seasonal phenomena in the life of the malaria mosquitoes in the Soviet Union. The collection of works by antimalarial institutions. Edited by Beklemishev VN, Shipitsina NK. Moscow: Inst Mal Med Parasitol and Helminthol Publ; 1957:165-171 [in Russian].

39. Pozdeev TS: Dates of outfly of Anopheles maculipennis from the wintering shelters and the survival of mosquitoes in the shelters with different micro-climates in the Udmurt ASSR. In Seasonal phenomena in the life of the malaria mosquitoes in the Soviet Union. The collection of works by antimalarial institutions. Edited by Beklemishev VN, Shipitsina NK. Moscow: Inst Mal Med Parasitol and Helmintol Publ; 1957:67-71 [in Russian]

40. Netzkii Gl: The results of phenological observations of Anopheles maculipennis in Omsk over 10 years (1940-1949). In Seasonal phenomena in the life of the malaria mosquitoes in the Soviet Union. The collection of works by antimalarial institutions. Edited by Beklemishev VN, Shipitsina NK. Moscow: Inst Mal Med Parasitol and Helminthol Publ; 1957:175-186.

41. Beklemishev VN: Ecology of the malaria mosquito. Moscow: Medgiz; 1944 [in Russian]

42. Vatandoost $\mathrm{H}$, Zahirnia AH: Responsiveness of Anopheles maculipennis to different imagicides during resurgent malaria. Asian Pac J Trop Med 2010, 3(5):360-363.

43. Kronefeld M, Dittmann M, Zielke D, Werner D, Kampen H: Molecular confirmation of the occurrence in Germany of Anopheles daciae (Diptera, Culicidae). Parasite Vector 2012, 5:250

44. Jaenson TGT, Lokki J, Saura A: Anopheles (Diptera: Culicidae) and malaria in northern Europe, with special reference to Sweden. J Med Entomol 1986, 23(1):68-75.

45. Ramsdale C, Snow K: Distribution of genus Anopheles in Europe. JEMCA (EMB) 2000, 7:1-26.

46. Sedaghat MM, Linton Y-M, Oshaghi MA, Vatandoost H, Harbach RE: The Anopheles maculipennis complex (Diptera: Culicidae) in Iran: molecular characterization and recognition of a new species. B Entomol Res 2003, 93:527-535.

47. Glick Jl: Illustrated key to the female Anopheles of southwestern Asia and Egypt (Diptera: Culicidae). Mosa Syst 1992, 24(2):125-153.

48. Habirov Z, Kadamov D, Iskandarov F, Komilova S, Cook S, McAlister E, Harbach RE: Malaria and the Anopheles mosquitoes of Tajikistan. J Vector Ecol 2012, 37(2):419-427.

\section{doi:10.1186/1756-3305-7-389}

Cite this article as: Novikov and Vaulin: Expansion of Anopheles maculipennis s.s. (Diptera: Culicidae) to northeastern Europe and northwestern Asia: Causes and Consequences. Parasites \& Vectors 2014 7:389.

\section{Submit your next manuscript to BioMed Central and take full advantage of:}

- Convenient online submission

- Thorough peer review

- No space constraints or color figure charges

- Immediate publication on acceptance

- Inclusion in PubMed, CAS, Scopus and Google Scholar

- Research which is freely available for redistribution 